\title{
DEVELOPMENT OF DISCUSSION LEARNING MODEL AND PERSONAL INVESTIGATION IN CLASSROOM SOCIOLOGY LEARNING XI IPS SMA MUHAMMADIYAH ENREKANG
}

\author{
Suparman $^{1 *}$, Tri Wijaya Darwis ${ }^{1}$, Putriyani Samsul ${ }^{2}$ \\ ${ }^{1}$ Department of Nonformal Education, Faculty of Teacher Training and Education, \\ Universitas Muhammadiyah Enrekang \\ Jendral Sudirman Street No 17, Enrekang, Indonesia. 91753 \\ *Email: suparmanpps25@gmail.com \\ ${ }^{2}$ Department of Mathematics Education, Faculty of Teacher Training and Education, \\ Universitas Muhammadiyah Enrekang \\ Jendral Sudirman Street No 17, Enrekang, Indonesia. 91753
}

\begin{abstract}
The learning model used by teachers does not vary, resulting in the activeness and independence of students in learning is reduced. Therefore, a new learning model needs to be developed that stimulate the activeness and independence of students, namely the discussion learning model and personal investigation. This research used a Research and Development (R\&D) approach. Researchers were focused on developing discussion learning models and personal investigations to be able developing a new learning model that can be applied in learning with clear steps according to scientific rules. The results of research were as follows: (1) students were more active in learning; (2) students no longer rely on friends when there are assignments or discussions; (3) problems that occur in learning can be analyzed by students easily; (4) Models could help foster a sense of responsibility in each student, especially responsibilities as a group member; and (5) the learning process in the class was more enjoyable. Based on the analysis of research results and discussions, it can be concluded that the development of discussion learning models and personal investigations that have been implemented in sociology learning has a positive impact both for students and teachers. Students were more active in learning, and students were more independent and better identify social problems. The discussion learning model and personal investigation are appropriately applied in sociology learning in the classroom. Based on the results of the research, it was suggested that: (1) teachers should use different learning models in the learning process so that students are more active in the following learning; (2) This new learning model can be used as a reference for teachers in doing classroom learning; and (3) Discussion learning models and investigative personals can be applied by teachers in sociology learning.
\end{abstract}

Keywords: discussion learning, personal investigation, sociology learning

\begin{abstract}
Abstrak: Model pembelajaran yang digunakan guru tidak bervariasi, mengakibatkan keaktifan dan kemandirian siswa dalam belajar menjadi berkurang. Oleh karena itu, perlu dikembangkan model pembelajaran baru yang dapat merangsang keaktifan dan kemandirian siswa yaitu model pembelajaran diskusi dan personal investigation. Penelitian ini menggunakan pendekatan Research and Development (R\&D). Peneliti difokuskan pada pengembangan model pembelajaran diskusi dan personal investigation untuk dapat mengembangkan model pembelajaran baru yang dapat diterapkan dalam pembelajaran dengan langkah-langkah yang jelas sesuai kaidah keilmuan. Hasil penelitian adalah sebagai berikut: (1) Siswa lebih aktif dalam belajar; (2) Siswa tidak lagi mengandalkan teman ketika ada tugas atau diskusi; (3) Masalah yang terjadi dalam pembelajaran dapat dianalisis oleh siswa dengan mudah; (4) Model dapat membantu menumbuhkan rasa tanggung jawab pada setiap siswa, terutama tanggung jawab sebagai anggota kelompok; dan (5) Proses pembelajaran di kelas lebih menyenangkan. Berdasarkan analisis hasil penelitian dan pembahasan maka dapat disimpulkan bahwa pengembangan model pembelajaran diskusi dan personal investigation yang telah diterapkan dalam pembelajaran sosiologi berdampak positif baik bagi siswa maupun guru. Siswa lebih aktif dalam pembelajaran, siswa lebih mandiri dan lebih baik dalam mengidentifikasi masalah sosial. Model pembelajaran diskusi dan investigasi pribadi cocok diterapkan dalam pembelajaran sosiologi di kelas. Berdasarkan hasil penelitian disarankan agar: (1) Guru sebaiknya menggunakan model pembelajaran yang berbeda dalam proses pembelajaran agar siswa lebih aktif dalam mengikuti pembelajaran; (2) Model pembelajaran baru ini dapat dijadikan acuan. Bagi guru dalam melakukan pembelajaran di kelas; dan (3) Model pembelajaran diskusi dan personal investigation dapat diterapkan oleh guru dalam pembelajaran sosiologi.
\end{abstract}

Kata Kunci: investigasi mandiri, pembelajaran diskusi, pembelajaran sosiologi 


\section{Introduction}

Education is a massive long-term capital that must be structured, prepared, and given its facilities and infrastructure in the sense of considerable material capital. However, until now, Indonesia still has many constraints on the classic problem of quality of education. This problem has been tried to find the root of the problem is like a circular link and do not know where to start solving it. Therefore, there needs to be work from various parties from schools, governments, and communities in solving this educational problem. The imaging of this education can start from the absence of learning activities in the school. The process between teachers and students to achieve the goals of education is applied in the curriculum.

Education is also an effort made by man and man with various devices, characters, and existence. The Qur'an is the word of Allah, which is then used as a guide (way of life) of Muslims who do not doubt it. The Qur'an itself has signaled that the issue of education is fundamental. If the Qur'an is reviewed more deeply, then we will find some basic principles of knowledge, which we can further inspire to develop to build a quality education. Education in the Qur'an covers a comprehensive aspect. One of the essential components that connect action with educational purposes is because educational materials can't be well received unless delivered correctly. Some types of methods excavated and developed from verses of the Qur'an include hiwar method, ibrah mau'izhah, amtsal, qishas, tajribah, targhib-tarhib, and uswatun hasanah (Za, 2014).

The Qur'an's view of education can be known its principles from the analysis of the first revelation received by the Prophet Muhammad in QS. Al-Alaq verses 1-5:

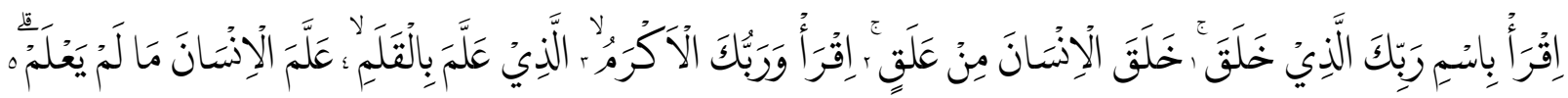

Meaning:

"1) Recite in the name of your Lord who created, 2) Created man from a clinging substance, 3) Recite, and your Lord is the most Generous, 4) Who taught by the pen, 5) Taught man that which be knew not".

The implementation of learning in the process is undoubtedly a problem; this is also the case in sociology learning in schools less in demand by students. Students think that sociology learning is monotonous and very dull. This is what should be changed in sociology learning. Teachers should provide an environment and learning conditions that encourage students to be active in them by changing conventional learning methods with methods that can stimulate students to be more active. Media also plays an essential role in the learning process to make it easier for students to understand the materials submitted (Pratiwi \& Hidayah, 2013; Marwa, 2013).

Sociology learning in grade XI is expected to have sensitivity and concern for social problems and social problem-solving responsibilities. After graduating from high school, students are expected to become citizens who have social awareness, sensitivity, and concern for environmental sustainability and social problems and overcome issues and do social empowerment in the community. Based on that competency, sociology learning is aimed at mastering knowledge in practice, or the way of sociological expertise, to develop social skills and foster a high attitude of religiosity and social ethics in social relations in society. The sociology learning process is carried out by emphasizing the importance of mastery of practice-oriented sociological knowledge to develop social skills and foster religious attitudes and social ethics as a form of student responsibility as an adult human being and citizen to social problems in society. Overall, it is intended to foster individual or self-awareness and social students amid existing social diversity or plurality, respect differences, and be tolerant of differences amid the prevalence of Indonesian society (Silabus Sosiologi Kurikulum 2013 Revision, 2016; Sylvia et al., 2019), as QS. Ahzab verse 72 said:

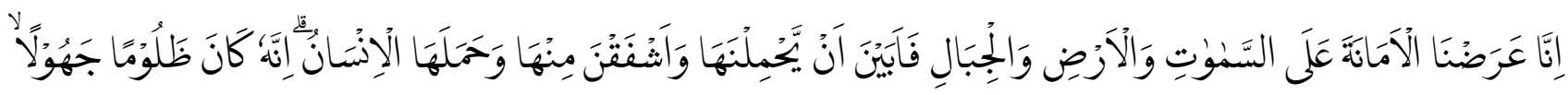

Meaning:

"Indeed, We offered the Trust [1214] to the heavens and the earth and the mountains, and they declined to bear it and 
feared it; but man [undertook to] bear it. Indeed, he was unjust and ignorant".

In this case, tarbiyah Islamiyah leads people to human behavior and actions that are guided by the sharia of Allah SWT. Man is said to be the subject of education because he is the perpetrator who acts and carries out the educational process. Man is said to be the object of knowledge because, in man, there are objects used as the basis of the rejection of educators to carry out education. Islamic education.

The discussion and personal investigation model are a learning model that combines individual discussion and investigation methods. This model focuses on the cooperation of the group and trains each student's individuals to be more critical in interpreting a material. The discussion and personal investigation model is a learning model in which students in the group exchange opinions on existing issues together to seek problemsolving, and after that, each student conducts an investigation and then records the facts found, revisits the suitability of the literature, and personally performs based on the source obtained (Sari et al., 2020).

\section{Materials and Methods}

This research used a Research and Development approach that aims to improve the quality of education. Besides, the R\&D approach seeks to discover new knowledge through "basic research," or to answer specific questions about practical issues through "applied research," which is used to improve educational practices. This study's procedures are as follows: potential and problems, data collection, product design, design validation, design revision, product trials, product revisions, usage trials, product revisions, and mass production. This research was done at Muhammadiyah Enrekang High School grade XI based on preliminary observations that researchers conducted for sociology learning taught by teachers still lacked applying existing learning models. Teachers often use lecture methods with conventional learning models. Therefore, researchers are trying to provide an innovative learning model that can help teachers and students to be able to develop themselves. Quality of the process is seen by observations of student activities and teacher activities. Observation sheets consisting of observation sheets of teacher and student activities and data collection using observation sheets, interviews, and documentation.

\section{Result and Discussion}

The results showed the development of discussion learning models and personal investigation further stimulated teachers in developing other learning models. So teachers are not just boxed in a method and a model of learning. In the process, the preparation of discussion and personal investigation learning models adjusted to competency standards, fundamental competencies, and learning objectives.

The implementation of learning model development certainly has a positive impact on students and teachers and the next stage of learning. The results of observations and interviews with some students on the development of discussion and personal investigation learning models concluded as follows: 1) Students are more active in learning; 2) Students no longer rely on friends when there are assignments or meetings; 3) Problems that occur in education can be analyzed by students easily; 4) It can foster a sense of responsibility to the student, primarily the responsibility of the group; and 5) The learning process in the classroom is more enjoyable.

Based on the data analysis results, students' cognitive abilities between classes improved from the initial condition before treatment. It means that students understand the material of Conflict, Civility, and peace associated with the circumstances in the community that students initially do not know. It is natural because students conducting their investigations are much easier to accept the lessons delivered.

Developing a discussion learning model and personal investigation implemented, researchers provide questionnaires and interviews with teachers and students. It is to know the response of students. So students are better able to analyze the problems they face and be more independent and active in learning.

The development of discussion learning models and personal investigation applied in learning makes students more active in small groups, cooperation, and discussion by engaging all students. This condition can show students' ability in its entirety, individual skills, and group abilities. Students play an active role in developing discussion and personal investigation learning models, while teachers only 
motivate and direct students in teaching and learning activities. This learning model is more impartial and empowers students and encourages students to construct knowledge in their minds.

The learning process takes place naturally in the form of activities students work and experience, not the transfer of knowledge from teacher to student. Data obtained from student responses showed students like the models that researchers develop because they differ from existing learning models supported by more conducive classroom conditions during learning implementation. This discussion and personal investigation learning model's advantages include: (1) student-centered learning, students are more active; students are more critically thinking and independent. (2) The learning process of teaching in the classroom is more enjoyable, and the class's condition is alive with the role of the student in learning.

The obstacles in implementing this learning model only at the beginning of students' application are somewhat confused because students did not understand, and students were familiar with the old learning models and methods. Students got explanations from teachers about discussion and personal investigation learning models, and students implemented this learning model by themselves. Students understand and gave a positive response to this discussion and personal investigation learning model.

Based on the above explanation, teachers and students are an essential factor in the classroom's learning process. One of the roles of teachers as the central element in the learning process certainly requires students' involvement to achieve the goal of learning. Therefore teachers need to develop learning models as variations in learning, especially in sociology learning.

\section{Conclusions}

Based on the analysis of the results of research and discussion, it concluded that the development of discussing and personal investigation learning models that have been implemented in sociology learning in grade XI IPS is composed of products in the form of discussion learning modules and personal investigations that can be used by sociology teachers in high school in sociology learning. Discussion learning models and personal investigations have a positive impact both for students and teachers. Students' activities in the learning process were more active, and students were more independent and can also identify sociological events well. Overall, the implementation model of discussion and personal investigation learning model was better than the learning model that teachers have implemented so far, using the question and answer method. Therefore, the discussion learning model and personal investigation implemented in sociology learning is feasible and appropriately applied in sociology learning in the classroom.

\section{Acknowledgements}

The authors would like to thank the support of Principal of SMA Muhammadiyah Enrekang and gratefully acknowledge funding provided by the Direktorat Riset dan Pengabdian Masyarakat, Kementerian Riset dan Teknologi/Badan Riset dan Inovasi Nasional.

\section{References}

Marwa, Yorisa Yora., and Reno Fernandes. 2013. "Penerapan Rencana Pelaksanaan Pembelajaran dalam Pembelajaran Sosiologi (Studi Kasus SMAN 3 Painan dan SMAN 2 Bayang)." Jurnal Sikola: Jurnal Kajian Pendidikan dan Pembelajaran 1(1): 14-19. doi: 10.24036/sikola.v1i1.2.

Pratiwi, Poerwanti Hadi., Nur Hidayah., and Aris Martiana. 2013. "Pengembangan Modul Mata Kuliah Penilaian Pembelajaran Sosiologi Berorientasi HOTS." Cakrawala Pendidikan Jurnal Ilmiah Pendidikan 36(2): 201-209. doi: 10.21831/cp.v36i2.13123.

Sari, Pratiwi Indah., Kartika Dewi., and Fitri Ayuningsih. 2020. "Pengembangan Model Pembelajaran Diskusi dan Personal Investigation dalam Meningkatkan Pemahaman Mahasiswa pada Mata Kuliah Evaluasi Pembelajaran di Universitas Batanghari." Jurnal Ilmiah Universitas Batanghari Jambi 20(3): 778-783. doi: 10.33087/jiubj.v20i3.1060.

Sylvia, Ike., Syafri Anwar., and Khairani Khairani. 2019. "Pengembangan Instrumen Penilaian Autentik berbasis Pendekatan Authentic Inquiry Learning Pada Mata Pelajaran Sosiologi di Sekolah Menengah Atas." Jurnal Socius: Journal of Sociology Research and Education 6(2): 103-120. doi: 10.24036/scs.v6i2.162.

Za, Tabrani. 2014. Menelusuri Metode Pendidikan Dalam Al-Qur 'An dengan Pendekatan Tafsir Maudhu." Serambi Tarbawi: 
Jurnal Studi Pemikiran, Riset dan Pengembangan Pendidikan Islam 2(1): 19-34. 